\title{
Pengaruh Kompensasi terhadap Kinerja Karyawan di Perusahaan Jasa Pengiriman di Kota Serang Indonesia
}

\author{
Didi Wandi \\ Program Studi Manajemen, Sekolah Tinggi Ilmu Ekonomi Banten \\ Jalan Letnan Jidun No.7C Kepandean, Kota Serang, Banten, Indonesia \\ didi.wandi81@gmail.com \\ Heri Sapari Kahpi* \\ Program Studi Manajemen, Sekolah Tinggi Ilmu Ekonomi Banten \\ Jalan Letnan Jidun No.7C Kepandean, Kota Serang, Banten, Indonesia \\ heri.kahpi1976@gmail.com
}

Fidziah

Program Studi Manajemen, Sekolah Tinggi Ilmu Ekonomi Banten

Jalan Letnan Jidun No.7C Kepandean, Kota Serang, Banten, Indonesia

\section{fidziah213@gmail.com}

\section{Zaenal Abidin}

Program Studi Manajemen, Sekolah Tinggi Ilmu Administrasi Banten

Jalan Letnan Jidun No.7C Kepandean, Kota Serang, Banten, Indonesia zal_din_af@yahoo.co.id

Diterima: 27-11-2020 | Disetujui: 24-12-2021 | Dipublikasi: 31-01-2022

\begin{abstract}
ABSTRAK
Pemberian kompensasi merupakan salah satu aspek yang paling penting bagi karyawan maupun organisasi. kompensasi atau balas jasa dapat diberikan atas dasar kinerja individu, kelompok maupun kinerja perusahaan secara keseluruhan ini untuk meningkatkan kinerja karyawan akhirnya tercapai tujuan organisasi. Penelitian ini bertujuan untuk mengetahui pengaruh pemberian kompensasi dalam bentuk finansial maupun non finansial terhadap kinerja karyawan jasa pelayanan pengiriman barang di kota Serang Indonesia. Sampel dalam penelitian ini berjumlah 90 karyawan. Metode yang digunakan metode kuantitatif. Teknik pengumpulan data yang digunakan adalah kuesioner. Analisis data menggunakan regresi linier berganda. Hasil penelitian menunjukan secara parsial bahwa kompensasi finansial berpengaruh positif dan signifikan terhadap kinerja karyawan, dan kompensasi non finansial berpengaruh positif dan signifikan terhadap kinerja karyawan. Secara simultan bahwa kompensasi finansial dan non finansial berpengaruh terhadap kinerja karyawan.
\end{abstract}

Kata Kunci:

Kompensasi Finansial; Kompensasi Non Finansial; Kinerja karyawan.

\begin{abstract}
Compensation is one of the most important aspects for employees and organizations. Can give compensation or remuneration based on individual, group, and company performance as a whole to improve employee performance and ultimately achieve organizational goals. This study aims to determine the effect of financial and non-financial compensation on the performance of employees of freight forwarding services in the city of Serang, Indonesia. The sample in this study amounted to 90 employees. The method used is the quantitative method. The data collection technique used was a questionnaire. Data analysis used multiple linear regression. The results show partially that financial compensation has a positive and significant effect on employee performance, and non-financial compensation has a positive and significant impact on employee performance. Simultaneously, financial and non-financial compensation affects employee performance.
\end{abstract}

Keywords:

Financial Compensation; Non-Financial Compensation; Employee Performance. 


\section{PENDAHULUAN}

Pada masa sekarang ini, perusahaan dituntut untuk lebih efisien, efektif dan ekonomis dalam menentukan besarnya biaya operasional. Hal ini merupakan faktor sangat penting dalam menghadapi persaingan yang ketat dengan perusahaan yang lain. Menyadari pentingnya sumber daya manusia untuk kelangsungan hidup suatu perusahaan, maka sudah tentu perusahaan memberikan perhatian lebih pada faktor produksi ini dan bagi pengusaha harus menjadikan sumber daya manusia yang ada sebagai mitra dalam usaha (Fredriksz, 2017).

Meningkatnya kompetisi di bidang jasa pengiriman ini menuntut tiap perusahaan wajib mampu mengembangakan serta memberdayakan sumber energi yang dipunyai. Salah satu umpan balik yang wajib didapatkan oleh karyawan merupakan pemberian kompensasi, supaya karyawan bisa bekerja dengan optimal. Pemberian kompensasi pada karyawan akan meningkatkan pada kinerja (Suseno et al., 2014). Pemberian kompensasi yang cocok dengan tipe pekerjaan, menciptakan karyawan terdorong dalam menaikkan kinerjanya karena salah satu sebab utama seseorang buat bekerja lebih buat penuhi kebutuhan hidupnya (Afrida et al., 2014). Kompensasi menjadi salah satu faktor terpenting dalam memotivasi seseorang dalam meningkatkan kinerja pegawai (Suherman, 2021).

Aspek pemberian kompensasi bagaikan salah satu motif untuk karyawan dalam berusaha. Kompensasi yang diberikan untuk karyawan sebagai kewajiban perusahaan memenuhi tepat waktu, adil serta bersumber pada hasil kerja (Firmandari, 2014). Hingga dari itu, kompensasi tidak cuma mempengaruhi buat kelangsungan hidup suatu perusahaan, akan tetapi kompensasi dapat memberikan sebuah motivasi atau tujuan bagi karyawan untuk ikut serta dalam meningkatkan kemampuan individu masing-masing (Ardiana et al., 2018).

Kompensasi adalah semua bentuk upah atau imbalan yang berlaku bagi karyawan dan muncul dari pekerjaan mereka, dan merupakan salah satu alat untuk memotivasi dan sekaligus sebagai jalur pengembangan yang strategis untuk mengoptimalkan sumber daya manusia yang bermutu (Suaedah, 2020). Menurut Purnawati et al., (2020) bahwa kompensasi merupakan suatu yang diterima karyawan untuk balas jasa kerja mereka.

Menurut Samudra et al., (2014) "kompensasi adalah semua pemberian dari perusahaan atau organisasi, baik berupa uang (finansial) maupun bukan uang (non finansial) kepada karyawan sebagai balas jasa atas kerja yang telah dilakukan bagi perusahaan". Menurut Suseno et al., (2014) "kompensasi merupakan segala sesuatu pemberian yang diberikan oleh perusahaan kepada karyawan sebagai balas jasa atas kerja mereka kepada perusahaan".

Menurut Leonardo \& Andreani, (2015) menjelaskan bahwa "kompensasi dalam hal ini dikelompokkan dalam dua diantaranya yaitu kompensasi finansial dan kompensasi non finansial. Kompensasi finansial adalah kompensasi yang langsung diserahkan oleh perusahan terhadap karyawannya dalam bentuk upah atau bonus (Sutrisno, 2016). Menurut Leonardo \& Andreani, (2015) Indikator untuk mengukur kompensasi finansial diantaranya gaji merupakan pembayaran imbalan pada karyawan secara teratur, seperti tahunan, caturwulan, bulanan atau mingguan.Tunjangan merupakan 
Wandi, D., et.al. (2022). Pengaruh Kompensasi terhadap Kinerja Karyawan ....

pemberian kompensasi oleh perusahaan pada karyawannya yang dianggap telah ikut terlibat dalam mewujudkan tujuan perusahaan. Insentif merupakan pembayaran imbalan langsung pada karyawan dikarenakan tinggi dalam kinerja yang ditentukan organisasi.

Kompensasi non finansial menurut Rivai et al., (2014) merupakan pemberian kompensasi oleh perusahaan selain kompensasi finansial. Kompensasi non finansial digunakan oleh perusahaan untuk meningkatkan kesejahteraan para karyawannya agar nyaman di dalam bekerja. Kompensasi non finansial terdiri dari fasilitas perusahan, pujian, rasa nyaman dalam bekerja, peluang promosi jabatan, dan motivasi dari perusahan.

Peranan kompensasi finansial ataupun non finansial sangat berarti untuk memotivasi dalam peningkatan kinerja di tempat mereka bekerja (Afrida et al., 2014). Setiap keputusan perusahaan perihal kompensasi pun akan berdampak pada kinerja setiap individu karyawan masing-masing. Menurut Zain \& Yuliana, (2017) bahwa kompensasi menjadi bagian faktor yang dominan dalam mendorong seseorang untuk meningkatkan kinerja. Selain itu juga, kompensasi juga sebagai pemelihara untuk tetap bertahan seorang karyawan. Rasa keadilan dalam pertimbangan pemberian kompensasi pada karyawan harus sesuai peraturan yang berlaku. Kompensasi ini, sehingga akan memberikan rangsangan kepada karyawan untuk tetap bekerja demi mendapatkan penghasilan (Buntarti \& Udjang, 2015). Hasil ini sesuai dengan penelitian yang dikemukakan oleh Wiguna et al., (2016) menyatakan bahwa untuk meningkatkan kapasitas kinerja karyawan adalah dengan menghubungkan kompensasi dengan perkembangan karyawan akhirnya akan memotivasi karyawan agar lebih meningkatkan kinerjanya.

Pendapat Mangkunegara (2016) "Kinerja adalah hasil kerja secara kualitas dan kuantitas yang dicapai oleh seorang pegawai dalam melaksanakan tugasnya sesuai dengan tanggung jawab yang diberikan kepada karyawan". Menurut Suseno et al., (2014) "Kinerja adalah hasil kerja yang dicapai oleh seorang karyawan dalam suatu organisasi”. Menurut Afrida et al., (2014) bahwa dengan hasil kerja yang dicapai oleh seorang karyawan dalam melakukan suatu pekerjaan dapat di evaluasi tingkat kinerja pegawainya, maka kinerja karyawan harus dapat ditentukan dengan pencapaian target selama periode waktu yang dicapai organisasi.

Menurut Firmandari, ( 2014) bahwa "Kinerja merupakan hasil akhir kerja dari proses kerja yang telah dilakukan seorang karyawan dalam periode tertentu, dengan menggunakan ide dan usaha untuk mencapai tujuan kerja perusahaan". sehingga dengan adanya kompensasi karyawan akan meningkatkan kerjanya. Dalam hal menciptakan hubungan kerjasama yang baik dalam peningkatan kinerja perusahan harus ada pemberian kompensasi yang tepat bagi keinginan karyawan dan juga kemampuan perusahaan. Kinerja merupakan suatu output pekerjaan yang akan sama dengan fungsi yang bebankan oleh masing-masing pegawai atau unit-unit kerja dalam masa tertentu (Kahpi et al., 2017). Menurut Leonardo \& Andreani (2015) indikator kinerja yaitu kualitas, kuantitas, pelaksanaan tugas serta tanggung jawab. Menurut Suseno et al., (2014)“ Kompensasi dan kinerja karyawan merupakan dua faktor yang berkaitan karena pemberian kompensasi akan membawa dampak bagi karyawan yang bersangkutan maupun perusahaan dimana dia bekerja". 
Adanya kesenjangan fenomena kompensasi terhadap kinerja karyawan, ternyata variabel kompensasi mempunyai pengaruh yang beragam terhadap kinerja. Menurut Manurung, (2020) bahwa kompensasi terhadap kinerja dosen terbukti berpengaruh positif dan signifikan. Demikian pula dengan penelitian (Arif et al., 2019); Wiguna et al., (2016) bahwa terdapat pengaruh kompensasi terhadap kinerja karyawan dalam bekerja. Sedangkan menurut penelitian Buntarti dan Udjang (2015) bahwa "kompensasi tidak berpengaruh secara parsial terhadap kinerja". Dengan adanya kesenjangan penelitian antara pengaruh kompensasi terhadap kinerja karyawan yang sudah dikemukakan oleh peneliti, untuk penelitian ini untuk membedakan maka peneliti ingin mengetahui dimensi kompensasi yaitu kompensasi finansial dengan kompensasi non finansial terhadap kinerja karyawan.

Finansial salah satu bagian dari wujud kompensasi ini menjadi suatu yang yang sangat penting bagi pegawai sebagai individu, karena besarnya jumlah finansial ini masih selalu dianggap mencerminkan standar hasil karya pegawai di antara para pegawai itu sendiri (Samudra et al., 2014). Menurut (Jufrizen, 2017) “Kompensasi memegang peranan penting dalam menciptakan kinerja pegawai/karyawan karena salah satu alasan utama orang bekerja adalah untuk memenuhi kebutuhan hidupnya dan kompensasi dari perusahaan merupakan sumber pendapatan untuk karyawan”.

Kompensasi finansial diberikan sesuai dengan kesepakatan yang terjadi antara perusahan dan karyawan. Kompensasi ini akan meningkatkan motivasi karyawan dalam bekerja sehingga kinerja mereka pun akan baik (Sari et al., 2016). Hal tersebut sesuai dengan penelitian (Widiantari et al., 2015; Yahyo et al., 2013) menunjukan bahwa kompensasi finansial berpengaruh positif dan signifikan terhadap kinerja karyawan.

$\mathrm{H}_{1}$ : Kompensasi finansial berpengaruh terhadap kinerja karyawan

Kompensasi sangat memberikan pengaruh terhadap kinerja karyawan. kompensasi disebut juga pengahargaan ini merupakan bentuk penghargaan yang diberikan pada karyawan sebagai balas jasa atas kontribusi yang karyawan kepada perusahaan atau organisasi (Firmandari, 2014). Dalam hal ini kompensasi non finansial menurut Leonardo \& Andreani, (2015) merupakan kompensasi yang diberikan oleh perusahan kepada karyawannya tanpa melihat karyawan yang satu dengan yang lainnya sehingga karyawan merasa nyaman di dalam bekerjanya. Sejalan dengan penelitian (Pratama et al., 2015; Suseno et al., 2014) bahwa kompensasi non finansial berpengaruh positif dan signifikan terhadap kinerja pegawai.

$\mathrm{H}_{2}$ : Kompensasi non finansial berpengaruh terhadap kinerja karyawan.

Faktor pendorong yang menyebabkan manusia bekerja dalam memenuhi kebutuhan hidup manusia yaitu dengan menjual tenaga, pikiran dan juga waktu yang dimiliki untuk perusahan dengan harapan mendapatkan kompensasi/imbalan (Hidayanto et al., 2014). Menurut (Pratama et al., 2015) kompensasi merupakan segala sesuatu bentuk balas jasa dari perusahan atas kinerja karyawan. Sari $e t$ al., (2016) bahwa pemberian kompensasi baik finansial maupun non finansial dapat membantu dan memotivasi karyawan dalam bekerja. tujuannya adalah meningkatkan kinerja dari karyawan selama bekerja. 
Wandi, D., et.al. (2022). Pengaruh Kompensasi terhadap Kinerja Karyawan ....

$\mathrm{H}_{3}$ : Kompensasi finansial dan kompensasi non finansial berpengaruh bersama-sama terhadap kinerja karyawan .

Berdasarkan kajian pustaka yang telah dijelaskan sebelumnya, dapat digambarkan kerangka konseptual penelitian sebagai berikut:

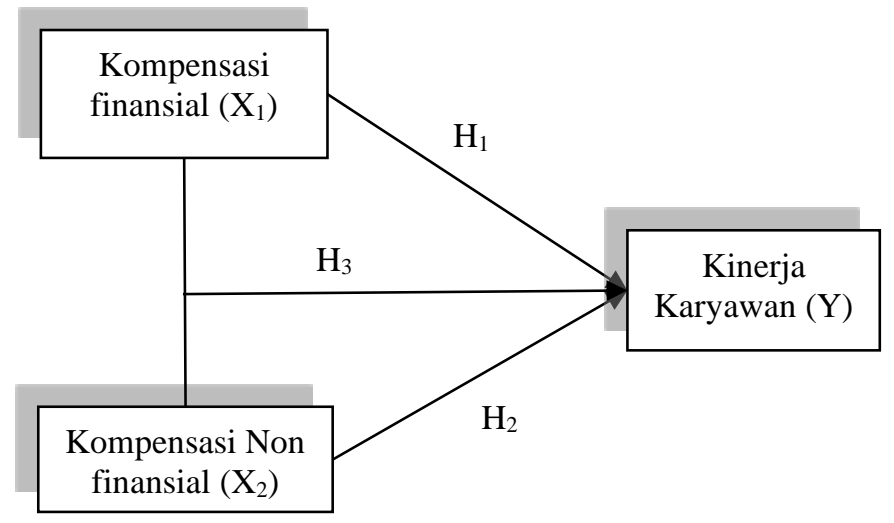

Gambar 1. Model Penelitian

\section{METODE RISET}

Menurut Mulyadi, (2011) bahwa penelitian kuantitatif merupakan menjelaskan untuk menguji hubungan antar variabel yang dihipotesiskan. Populasi adalah wilayah generalisasi yang terdiri atas objek dan subjek yang mempunyai kualitas dan karakteristik tertentu yang ditetapkan oleh peneliti untuk ditarik kesimpulannya (Sugiyono, 2018). Populasi dalam penelitian ini adalah seluruh Karyawan jasa pengiriman (JNE) wilayah Kota Serang Banten, seluruhnya berjumlah 200. Teknik penelitian sampel dalam penelitian ini menggunakan random sampling, artinya adalah pengambilan anggota sampel dari populasi dilakukan secara acak tanpa memperhatikan strata yang ada dalam populasi itu. Cara ini dilakukan bila anggota populasi dianggap homogen (Sugiyono, 2018). Pengambilan sampel menurut Ferdinand, (2014) sampel yang akan digunakan dalam penelitian ini ditentukan dengan menggunakan rumus :

Jumlah Sampel = Jumlah Indikator x 5 s/d 10

Karena dalam penelitian ini terdapat 10 indikator, maka jumlah sampel yang digunakan adalah:

Sampel minimum $=$ Jumlah indikator $\times 9=10$ indikator $\times 9=90$ responden .

Jadi jumlah yang diambil dalam penelitian untuk sampel yaitu 90 responden. Metode pengumpulan data pada penelitian ini adalah dengan menggunakan metode kuesioner. Data responden yang diambil menggunakan google form diperoleh dengan memberikan kuesioner pada responden dengan menggunakan jaringan online/internet (Sianipar, 2019). Teknik analisis data yang digunakan dalam penelitian ini adalah analisis statistik deskriptif dan analisis regresi linier berganda.

\section{HASIL PENELITIAN DAN PEMBAHASAN}

\section{Uji Validitas}

Dalam penelitian ini pengujian validitas data menggunakan metode korelasi Bivariate Pearson (Correlation Pearson Product Moment). Semakin tinggi ukuran validitas artinya semakin valid, 
semakin rendah ukuran validitas maka kurang valid (Arikunto, 2010). Berdasarkan tabel 1 menunjukan bahwa pada hasil uji validitas seluruh koefisien korelasi dari indikator variabel penelitian yang diuji nilainya $r_{\text {hitung }}>0,205$. Dengan demikian hasil ini menunjukkan seluruh indikator penelitian terbukti yaitu valid.

Tabel 1. Hasil Uji Validitas

\begin{tabular}{cccc}
\hline Vaiabel & No. Butir Pernyataan & Koefisien Validitas & Ket \\
\hline Kompensasi Finansial $\left(\mathrm{X}_{1}\right)$ & 1 & 0,833 & Valid \\
& 2 & 0,902 & Valid \\
Kompensasi Non Finansial $\left(\mathrm{X}_{2}\right)$ & 3 & 0,868 & Valid \\
& 4 & 0,884 & Valid \\
\multirow{3}{*}{ Kinerja Karyawan $(\mathrm{Y})$} & 5 & 0,867 & Valid \\
& 6 & 0,869 & Valid \\
& 7 & 0,820 & Valid \\
& 9 & 0,820 & Valid \\
& 10 & 0,800 & Valid \\
& 9 & 0,840 & Valid \\
\hline
\end{tabular}

Sumber: Data primer yang diolah, 2020

\section{Uji Reliabilitas}

Menurut Arikunto (2010) reliabilitas adalah suatu instrumen cukup bisa dipercaya untuk digunakan sebagai alat pengumpul data karena instrumen tersebut sudah baik. Berdasarkan tabel 2, hasil uji reliabilitas Cronbach's Alpha bahwa semua variabel memiliki nilai Cronbach's Alpha > 0,60 yang artinya bahwa jawaban dari responden reliabel atau handal.

Tabel. 2 Hasil Uji Reliabilitas

\begin{tabular}{lcc}
\hline \multicolumn{1}{c}{ Variabel } & Cronbach's Alpha & Ket \\
\hline Kompensasi Finansial $\left(\mathrm{X}_{1}\right)$ & 0,836 & Reliabel \\
Kompensasi Non Finansial $\left(\mathrm{X}_{2}\right)$ & 0,854 & Reliabel \\
Kinerja Karyawan $(\mathrm{Y})$ & 0,821 & Reliabel \\
\hline \multicolumn{2}{c}{ Sumber: Data primer yang diolah, 2020} &
\end{tabular}

\section{Uji Hipotesis}

Hasil hipotesis didasarkan pada hubungan fungsional ataupun kausal variabel bebas dengan variabel tak bebas. Hasil analisis regresi linier berganda dapat dilihat pada tabel 3 berikut :

Tabel 3. Hasil Analisis Data

\begin{tabular}{lccc}
\hline \multicolumn{1}{c}{ Variabel } & Koefisien & t hitung & Sig. \\
\hline Constant & 3,910 & & \\
Kompensasi Finansial $\left(\mathrm{X}_{1}\right)$ & 0,356 & 3,886 & 0,000 \\
Kompensasi Non Finansial $\left(\mathrm{X}_{2}\right)$ & 0,686 & 7,548 & 0,000 \\
$R$ Square & 0,774 & Nilai Fhitung & 149,105 \\
$R$ Adjusted Square & 0,880 & Sig. & 0,000 \\
\hline \multicolumn{4}{c}{ Sumber: Data primer yang diolah, 2020} \\
\end{tabular}

Dari tabel 3 maka dapat dijelaskan melalui persamaan regresi linear berganda sebagai berikut:

$$
\begin{aligned}
& \dot{Y}=a+b_{1} X_{1}+b_{2} X_{2} \\
& Y=3,910+0,356 X_{1}+0,686 X_{2}
\end{aligned}
$$

Dari persamaan tersebut mempunyai pengertian sebagai berikut : 
Wandi, D., et.al. (2022). Pengaruh Kompensasi terhadap Kinerja Karyawan ....

1. Nilai 3,910 merupakan nilai konstanta yang berarti bahwa tidak ada variabel bebas atau tidak ada pengaruh dari variabel kompensasi finansial $\left(\mathrm{X}_{1}\right)$ dan kompensasi non finansial $\left(\mathrm{X}_{2}\right)$ yang mempengaruhi kinerja karyawan maka kinerja karyawan tetap.

2. Nilai koefisien 0,356 ini berarti terjadi peningkatan penilaian kinerja karyawan terhadap variabel kompensasi finansial sebesar satu satuan, maka kompensasi finansial meningkat sebesar 0,356 satuan atau sebesar 35,6\%.

3. Nilai koefisien 0,686 ini berarti terjadi peningkatan penilaian kinerja karyawan terhadap variabel kompensasi non finansial sebesar satu satuan, maka kompensasi non finansial akan meningkat sebesar 0,686 satuan atau sebesar $68,6 \%$.

\section{Koefisien Determinasi}

Analisis determinasi digunakan untuk mengetahui prosentase sumbangan pengaruh variabel kompensasi finansial dan kompensasi non finansial secara serentak terhadap variabel kinerja karyawan.

Tabel 4. Model Summary

\begin{tabular}{cc}
\hline Variabel & Cronbach's Alpha \\
\hline R Square & 0,774 \\
Sumber: Data primer yang diolah, 2020
\end{tabular}

Hasil perhitungan program komputer SPSS yang tertera pada tabel 4, nilai koefisiensi determinasi ( $R$ Square) adalah sebesar 0.774 atau $77.40 \%$, menunjukan bahwa kinerja karyawan dipengaruhi oleh kompensasi finansial dan kompensasi non finansial sebesar $77.40 \%$, sedangkan sisanya $22.60 \%$ dijelaskan oleh variabel lain diluar variabel yang diujikan.

\section{Pengujian Parsial (Uji-t)}

Uji-t adalah uji yang dipakai untuk mengetahui ada tidaknya pengaruh masing-masing variabel bebas secara parsial. Berikut adalah hasil output SPSS versi 22.0 mengenai untuk uji secara parsial :

1. Pengujian hipotesis kompensasi finansial terhadap kinerja karyawan

Nilai $t_{\text {hitung }}$ lebih besar dari tabel $(3,886>1.986)$ dan nilai Sig yaitu $0,000<0,05$ artinya $\mathrm{H}_{0}$ ditolak dan Ha diterima, berarti terdapat pengaruh positif dan signifikan kompensasi finansial terhadap kinerja karyawan.

2. Pengujian hipotesis kompensasi non finansial terhadap kinerja karyawan

Nilai $t_{\text {hitung }}$ lebih besar dari $\mathrm{t}_{\text {tabel }}(7.548>1.986)$ dan nilai Sig $0,000<0,05$ artinya $\mathrm{H}_{0}$ ditolak dan Ha diterima, berarti terdapat pengaruh positif dan signifikan kompensasi non finansial terhadap kinerja karyawan.

\section{Pengujian Simultan (Uji F)}

Uji ini digunakan untuk mengetahui apakah variabel-variabel independen berpengaruh secara simultan terhadap variabel dependen.

\begin{tabular}{|c|c|c|}
\hline $\mathrm{F}$ & 149,105 & da \\
\hline
\end{tabular}


Diperoleh $\mathrm{F}_{\text {hitung }}>\mathrm{F}_{\text {tabel }}(149,105>3.15)$ dan nilai sig $\mathrm{F}<\alpha(0,000<0,05)$. Maka dapat diambil kesimpulan bahwa terdapat pengaruh kompensasi finansial dan kompensasi non finansial secara bersama-sama terhadap kinerja karyawan.

\section{HASIL PENELITIAN DAN PEMBAHASAN}

Berikut adalah pembahasan hasil penelitian pengaruh kompensasi finansial dan kompensasi non finansial terhadap kinerja karyawan.

1. Pengaruh kompensasi finansial terhadap semangat kerja

Berdasarkan hasil hipotesis dan atas arah pengaruh variabel kompensasi finansial terhadap kinerja karyawan adalah 0,356 sebagaimana diperlihatkan oleh koefisien jalurnya pengujian. dilihat dari dihasilkan nilai $t_{\text {hitung }}$ lebih besar dari $t_{\text {tabel }}(3,886>1.986)$ dan nilai Sig. sebesar 0,000 lebih kecil dari $0,05(0,000<0,05)$ sehingga $\mathrm{H}_{0}$ ditolak dan $\mathrm{Ha}$ diterima, berarti terdapat pengaruh positif dan signifikan kompensasi finansial terhadap kinerja karyawan jasa pengiriman wilayah Kota Serang Banten.

Hasil penelitian ini sejalan dengan penelitian yang dilakukan Afrida et al., (2014) menyatakan bahawa kompensasi finansialmempunyai pengaruh positif dan signifikan terhadap kinerja karyawan. Menurut Sari et al., (2016) bahwa kompensasi finansial diberikan sesuai dengan kesepakatan yang terjadi antar perusahaan dengan karyawan. Kompensasi yang diberikan secara baik oleh perusahaan kepada karyawan akan meningkat motivasi karyawan dalam bekerja sehingga kinerja mereka pun akan baik. Hasil penelitian menunjukan bahwa kompensasi finansial yaitu gaji, tunjangan dan insentif yang ada di jasa pengiriman wilayah Kota Serang Banten masih perlu diperhatikan.

2. Pengaruh kompensasi non finansial terhadap kinerja karyawan

Berdasarkan hasil hipotesis dan atas arah pengaruh variabel kompensasi finansial terhadap kinerja karyawan adalah 0, 686 sebagaimana diperlihatkan oleh koefisien jalurnya pengujian. dilihat dari dihasilkan nilai thitung lebih besar dari $t_{\text {tabel }}(7.548$ > 1.986) dan nilai Sig sebesar 0,000 lebih kecil dari $0,05(0,000<0,05)$ sehingga $\mathrm{H}_{0}$ ditolak dan $\mathrm{Ha}$ diterima, berarti terdapat pengaruh positif dan signifikan kompensasi non finansial terhadap kerja karyawan jasa pengiriman Wilayah Kota Serang Banten.

Hasil penelitian ini sejalan dengan penelitian yang dilakukan (Leonardo \& Andreani, 2015; Samudra et al., 2014) menyatakan bahwa variabel kompensasi non financial mempunyai pengaruh positif dan signifikan terhadap variabel kinerja karyawan. Sesuai dengan teori menurut Hasibuan, (2008) menyatakan bahwa kompensasi yang diterapkan dengan baik akan memberikan motivasi kerja bagi karyawan.

3. Pengaruh kompensasi finansial dan kompensasi non finansial terhadap semangat kerja

Berdasarkan hasil penelitian dan pengujian data dihasilkan nilai uji $\mathrm{F}$ kompensasi finansial dan kompensasi non finansial terhadap kinerja karyawan diperoleh $F_{\text {hitung }}>F_{\text {tabel }}(149,105>3.15)$ dan nilai $\operatorname{sig} \mathrm{F}<\alpha(0,000<0,05)$. Maka dapat diambil kesimpulan bahwa terdapat pengaruh kompensasi finansial $\underline{\text { dan kompensasi non finansial secara bersama-sama terhadap kinerja karyawan jasa pengiriman wilayah }}$ 
Wandi, D., et.al. (2022). Pengaruh Kompensasi terhadap Kinerja Karyawan ....

Kota Serang Banten. Hasil uji determinasi didapatkan semangat kerja dipengaruhi kompensasi finansial dan kompensasi non finansial sebesar 77,40\%.

Hasil penelitian ini sejalan dengan penelitian yang dilakukan (Hamid et al., 2014; Wiguna et al., 2016) variabel kompensasi finansial dan kompensasi non finansial secara simultan berpengaruh positif dan signifikan terhadap kinerja karyawan.

\section{KESIMPULAN DAN SARAN}

\section{Kesimpulan}

Hasil analisis data penelitian dan pembahasan maka dapat disimpulkan sebagai berikut :

1. Kompensasi finansial berpengaruh positif dan signifikan terhadap kinerja karyawan jasa pengiriman wilayah Kota Serang Banten.

2. Kompensasi non finansial berpengaruh positif dan signifikan terhadap kinerja karyawan jasa pengiriman wilayah Kota Serang Banten.

3. Kompensasi finansial dan kompensasi non finansial berpengaruh bersama-sama terhadap kinerja karyawan jasa pengiriman wilayah Kota Serang Banten.

\section{Saran}

Berdasarkan kesimpulan yang telah dibuat penulis, maka selanjutnya penulis memberikan saran-saran yang dapat berguna mengenai kompensasi finansial dan motivasi terhadap semangat kerja karyawan di perusahan yaitu:

1. Perusahaan juga harus memperhatikan variabel kompensasi finansial besaran gaji harus sesuai dengan peraturan yang berlaku, besaran gaji yang sesuai dengan harapan karyawan, besaran insentif sesuai dengan tanggung jawab, dan besaran insentif sesuai dengan prestasi kerja. Faktor-faktor tersebut harus diperhatikan agar dapat meningkatkan kinerja karyawan jasa pengiriman wilayah Kota Serang Banten kedepannya.

2. Kompensasi non finansial adanya persepsi belum adanya pujian dari pimpinan padahal ini lebih mudah dijalankan dari pimpinan pada karyawan sehingga karyawan merasa dihargai. 


\section{DAFTAR PUSTAKA}

Afrida, Z., Sunuharyo, B. S., \& Astuti, E. S. (2014). Motivasi Kerja Dan Kinerja Karyawan ( Studi Pada Karyawan Departemen Produksi PT . Ekamas Fortuna Malang ). Jurnal Administrasi Bisnis, 12(1), 1-9.

Ardiana, I. D. P., Natsir, S., \& Kornelius, Y. (2018). Pengaruh Kompensasi Non Finansial, Disiplin Kerja dan Motivasi Terhadap Kinerja Pegawai Di Kementerian Agama Kabupaten Donggala. Jurnal Ilmu Manajemen Univeristas Tadulako, 4(1), 61-70.

Arif, M., Syaifani, P. E., Siswadi, Y., \& Jufrizen, J. (2019). Effect of Compensation and Discipline on Employee Performance. Proceeding of The 3rd International Conference on Accounting, Business and Economics, 1(1), 263-276.

Arikunto, S. (2010). Prosedur Penelitian Suatu Pendekatan Praktik. Rineka Cipta.

Buntarti, R. S., \& Udjang, R. (2015). Karyawan Dengan Lama Bekerja Sebagai Variabel. Jurnal Perilaku Dan Strategi Bisnis, 3(2), 1-9.

Ferdinand, A. (2014). Metode Penelitian Manajemen Pedoman Penelitian untuk Penulisan Skripsi, Tesis, dan Disertasi Ilmu Manajemen (3rd ed.).

Firmandari, N. (2014). Pengaruh Kompensasi Terhadap Kinerja Karyawan Dengan Motivasi Kerja Sebagai Variabel Moderasi (Studi Pada Bank Syariah Mandiri Kantor Cabang Yogyakarta). Ekbisi, IX(1), 25-34.

Fredriksz, G. (2017). Pengaruh Kompensasi Finansial Dan Kompensasi Nonfinansial Terhadap Kinerja Karyawan. Jurnal Penelitian Manajemen Terapan (PENATARAN), 2(2), 143-152. http://journal.stieken.ac.id/index.php/penataran/article/view/327

Hamid, D., Suseno, S., \& Ruhana, I. (2014). Kinerja Karyawan (Studi pada Bank Rakyat Indonesia Cabang Jember). Jurnal Administrasi Bisnis (JAB) Vol. 8 No. 2 Maret 2014, 8(2), 1-6.

Hasibuan, M. (2012). Manajemen Sumber Daya Manusia. PT.Bumi Aksara.

Hidayanto, A., Hamid, D., \& Hakam, M. S. (2014). Motivasi Dan Kinerja Karyawan ( Studi Pada Karyawan PT . AXA Financial Indonesia Cabang Malang ). Jurnal Administrasi Bisnis (JAB), 10(1), 1-9. 
Wandi, D., et.al. (2022). Pengaruh Kompensasi terhadap Kinerja Karyawan ....

Jufrizen, J. (2017). Efek Mediasi Kepuasan Kerja Pada Pengaruh Kompensasi Terhadap Kinerja Karyawan. Jurnal iImiah Manajemen Dan Bisnis, 17(1), 34-53.

Kahpi, H. S., Khurosaini, A., \& Suhendra, I. (2017). Pengaruh Pelatihan dan Motivasi Berprestasi Terhadap Kinerja Pegawai dengan Kompetensi Sebagai Variabel Intervening (Studi Empiris Pada Pegawai Perusahan Daerah Air Minum Kabupaten Lebak). Jurnal Riset Bisnis Dan Manajemen Tirtayasa (JRBMT), 1(1), 1-9.

Leonardo, E., \& Andreani, F. (2015). Pengaruh pemberian Kompensasi terhadap Kinerja Karyawan pada PT. Kopanitia. Agora, 3(2), 28-31.

Mangkunegara, A. A. A. P. (2016). Manajemen Sumber Daya Manusia Perusahaan. PT. Remaja Rosdakarya.

Manurung, E. F. (2020). The Effects of Transformational Leadership, Competence and Compensation on Work Motivation and Implications on the Performance of Lecturers of Maritime College in DKI Jakarta. International Journal of Multicultural and Multireligious Understanding, 7(6), 112. https://doi.org/10.18415/ijmmu.v7i6.1741

Mulyadi, M. (2011). Penelitian Kuantitatif Dan Kualitatif Serta Pemikiran Dasar Menggabungkannya. Jurnal Studi Komunikasi Dan Media, 15(1), 128.

Pratama, S. A., Hakam, M. S., \& Nurtjahjono, G. E. (2015). Pengaruh Kompensasi Terhadap Kinerja Karyawan ( Studi pada karyawan PT. Asuransi Jiwasraya persero regional office Malang ). Jurnal Administrasi Bisnis S1 Universitas Brawijaya, 25(1), 1-8.

Purnawati, E. B., Heryanda, K. K., \& Rahmawati, P. I. (2020). Pengaruh Kompensasi Dan Pengalaman Kerja Terhadap Kinerja Karyawan Pada Pt. Indo Bali Negara. Prospek: Jurnal Manajemen Dan Bisnis, 1(2), 41. https://doi.org/10.23887/pjmb.v1i2.23153

Rivai, V., Ramlly, M., Mutis, T., \& Arafah, W. (2014). Manajemen Sumber Daya Manusia Untuk Perusahaan (3rd ed.). Raja grafindo persada.

Samudra, A. P., Rahardjo, K., \& Mukzam, M. D. (2014). Pengaruh Kompensasi Finansial Terhadap Kinerja (Studi pada Karyawan PT. Bank Jatim Cabang Malang). Jurnal Administrasi Bisnis S1 Universitas Brawijaya, 7(2), 78757.

Sari, G. A. W. P., Dewi, L. G. L. K., \& Mahadewi, N. P. (2016). Pengaruh Kompensasi Finansial Dan Kompensasi Non- Finansial Terhadap Kinerja Karyawan Pada Pt. Angkasa Pura I (Persero) Bandar Udara Internasional Ngurah Rai Bali. Jurnal IPTA, $4(2), \quad 82$. 
https://doi.org/10.24843/ipta.2016.v04.i02.p17

Sianipar, A. Z. (2019). Penggunaan Google Form Sebagai Alat Penilaian Kepuasan Pelayanan Mahasiswa. JISAMAR, 3(1), 16-22.

Suaedah, S. (2020). Pengaruh Kompetensi Profesional, Kompensasi, dan Disiplin terhadap Kinerja Guru. SAP (Susunan Artikel Pendidikan), 5(2), 177-181. https://doi.org/10.30998/sap.v5i2.7698

Sugiyono. (2018). Metode Penelitian Manajemen (Setiyawami (ed.)). Alfabeta.

Suherman, A. (2021). Pengaruh Kompetensi , Kompensasi , Disiplin Kerja terhadap Kinerja Guru pada Lazuardi Global Islamic School. Journal of Management and Business Review, 18, 614-629.

Suseno, E. S., Hamid, D., \& Ruhana, I. (2014). Kinerja Karyawan (Studi pada Bank Rakyat Indonesia Cabang Jember). Jurnal Administrasi Bisnis (JAB) Vol. 8 No. 2 Maret 2014, 8(2), 1-6.

Sutrisno, E. (2016). Manajemen Sumber Daya Manusia. Kencana Prenada Media Group.

Widiantari, Ningsih, D. S., \& Wasnury, R. (2015). Pengaruh Kepemimpinan dan Lingkungan Kerja Terhadap Semangat Kerja Pegawai Puskesmas Sidomulyo Pekanbaru. 2(1), 1-15.

Wiguna, I. K. D. D., Mahadewi, N. P. E., \& Wijaya, N. M. S. (2016). Pengaruh Kompensasi Terhadap $\begin{array}{lllllll}\text { Kinerja Di Pt Bali Daksina Wisata. Jurnal IPTA, } & \text { 4(2), }\end{array}$ https://doi.org/10.24843/ipta.2016.v04.i02.p16

Yahyo, W, H. D., \& Dewi, R. S. (2013). Pengaruh Motivasi, Lingkungan Kerja dan Kompensasi Terhadap Kinerja Karyawan Melalui Semangat Kerja ( Studi Kasus Pada Karyawan Bagian Produksi CV . Putra Jaya Sahitaguna Semarang). Diponogoro Journal Of Social And Polictic, 112.

Zain, R., \& Yuliana, A. T. R. D. (2017). Pengaruh Kompensasi dan Kepuasan Kerja terhadap Kinerja Dosen di Fakultas Ilmu Tarbiyah dan Keguruan UIN Sunan Kalijaga Yogyakarta. MANAGERIA: Jurnal Manajemen Pendidikan Islam, 2(1), 107-126. https://doi.org/10.14421/manageria.2017.21-06 